\title{
Winter decrease of zooplankton abundance and biomass in subalpine oligotrophic Lake Atnsjøen (SE Norway)
}

\author{
Thomas C. JENSEN* \\ Norwegian Institute for Nature Research, Landscape Ecology Dept., Gaustadalléen 21, 0349 Oslo, Norway
}

\begin{abstract}
Despite the rapidly changing winter conditions in temperate ecosystems, little attention has been devoted to the effects of these changes on lake ecology. Few studies on the seasonal changes in abundance and biomass of the major groups of the metazooplankton community (i.e, rotifers, cladocerans and copepods) in northern oligotrophic lakes include data from the ice-covered winter months. This study reports monthly variation in zooplankton abundance and biomass from June 2010 to October 2011, including winter, in an oligotrophic, subalpine lake in southeastern Norway (Lake Atnsjøen). Changes in rotifer, cladoceran, copepod, and total zooplankton abundances and biomass were related to seasonal variation in water temperature and phytoplankton biomass by means of ordination analysis. The zooplankton abundance and biomass were much lower in winter than during the open water season. However, an underice phytoplankton bloom occurred during the final winter months, when snow cover and ice thickness were reduced and (presumably) light penetration increased, leading to an increase in abundance of copepod nauplii. Winter zooplankton abundance was dominated by copepods and rotifers, while winter zooplankton biomass was dominated by copepods and cladocerans. Both phytoplankton and zooplankton had two biomass peaks in 2010 and one peak in 2011. Rotifers dominated zooplankton abundance with a peak in August and total zooplankton abundance followed a similar pattern. In contrast, cladocerans dominated zooplankton biomass with a peak in July and total zooplankton biomass also peaked at this time. Rotifer and total zooplankton abundance and rotifer biomass were most closely correlated to water temperature. However, cladoceran biomass and total biomass were most closely correlated with phytoplankton biomass, but also appeared to be dependent on other carbon sources. Estimates of non-phytoplankton particulate organic carbon indicated that this part of the carbon pool could be an additional food source for zooplankton particularly in early and mid-winter. The longer growing season in 2011 than in 2010, owing to earlier ice-off in 2011, may have contributed to higher phytoplankton and zooplankton biomass in 2011. With climate warming, this is an expected change in temperate lake ecosystems.
\end{abstract}

\section{INTRODUCTION}

Plankton communities in high latitude lakes exhibit significant seasonality because of large seasonal fluctuations of irradiance and temperature (Sommer et al., 1986; Winder and Cloern, 2010). The seasonal succession of the plankton community is one of the most well studied phenomena in freshwater ecology and well described in the PEG-model (Sommer et al., 1986). Initially, the model did not much consider the winter period (Sommer et al.,

Corresponding author: thomas.jensen@nina.no

Key words: Rotifers; cladocerans; copepods; winter limnology; ice; northern lakes.

Edited by: Giampaolo Rossetti, University of Parma, Italy.

Received: 5 December 2018.

Accepted: 6 September 2019.

This work is licensed under a Creative Commons Attribution NonCommercial 4.0 License (CC BY-NC 4.0).

${ }^{\circ}$ Copyright: the Author(s), 2019

Licensee PAGEPress, Italy

J. Limnol., 2019; 78(3): 348-363

DOI: 10.4081/jlimnol.2019.1877
1986). However, this period is of key importance for the seasonal dynamics of plankton communities (Post et al., 2009), and is not only an inactive period of dormancy (Salonen et al., 2009; Bertilsson et al., 2013; Hampton et al., 2015), as once believed. Thus, the PEG-model was revised and acknowledges the necessity of addressing the winter conditions for plankton dynamics (Sommer et al., 2012). For example, winter conditions may affect plankton dynamics the following year through cross-seasonal cascades (Hampton et al., 2017).

Zooplankton are an important part of aquatic food webs and also play an important role for the biochemical cycling of nutrients. Zooplankton are transferring organic carbon (hereafter C) and energy to higher trophic levels by grazing on phytoplankton, heterotrophic protists, and dead particulate organic matter. In the PEG-model the seasonality of the zooplankton is driven by a combination of changes in temperature, food availability, and predation. Temperature and food availability affect zooplankton directly via effects on growth rates and behavior (Urabe, 1991; Lampert and Trubetskova, 1996), and indirectly through thermally driven seasonal changes (e.g. stratification, Loose and Dawidowicz, 1994). In particular, zooplankton dynamics depend on lake trophic states (Sommer et al., 1986). For example, a generalized temperate eutrophic lake has two (or more) zooplankton peaks during the growing season. The first succeeds the phytoplankton spring bloom and the second trails the 
summer/autumn phytoplankton bloom. A generalized temperate oligotrophic lake has one zooplankton peak during the growing season, following the phytoplankton spring bloom (Sommer et al., 1986). However, there is considerable inter- and intra-lake variation in these patterns. The number of zooplankton peaks may change from year to year in the same lake (Halvorsen et al., 2004), likely reflecting annual variability in environmental conditions, demographic stochasticity, or fluctuating foodweb interactions. Despite the seasonal variability in zooplankton abundance, there are relatively few investigations reporting on the occurrence of zooplankton under winter ice, as compared to the growing season (Noges et al., 1998; Virro et al., 2009). In addition, winter studies are often limited to brief observations in studies dealing with other issues (Steinhart and Wurtsbaugh, 2003). There are almost no studies describing the seasonal changes in the zooplankton community of high latitude, oligotrophic lakes (Larsson, 1978).

There are major differences in life history strategies, food requirements, and predation resistance between rotifers, cladocerans, and copepods (Brooks and Dodson, 1965; Allan, 1976; Zaret, 1980; Andersen, 1997; Saksgård and Hesthagen, 2004; Hart and Bychek, 2011). Accordingly, the environmental factors that control the seasonal change in abundance and biomass of rotifers, cladocerans, and copepods may differ. There are increasing concerns about effects of climate warming on temperate and arctic lakes. The winter period is expected to be particularly impacted by climate change in ice-covered lakes, as many lakes are experiencing reduced periods of ice coverage (Benson et al., 2012). A longer growing season can affect the phenology of the plankton community, may lead to higher phytoplankton and zooplankton abundance in temperate oligotrophic lakes (De Senerpont Domis et al., 2012; Weyhenmeyer et al., 2013), and could change the predation regime because of changes in activity and metabolic requirements of fishes (Watz et al., 2015). In Greenland lakes, higher water temperatures linked to earlier ice-off was associated with higher biomass of phytoplankton and higher abundances of copepods and Daphnia. However, abundance of rotifers was lower in years with earlier ice-off (Christoffersen et al., 2008).

The present study examined seasonal changes in zooplankton abundance and biomass in an oligotrophic, subalpine lake, across the growing season (growing season and open water period are used interchangeably to refer to the ice-free period) and winter season (the ice-covered period). Seasonal changes in zooplankton abundance and biomass were related to changes in temperature and food availability. It was hypothesized that different zooplankton groups respond differently to temperature changes and resource availability.

\section{METHODS}

\section{Study site}

The study was conducted in Lake Atnsjøen ( $61^{\circ} 52^{\prime} 51$ $\mathrm{N}, 10^{\circ} 09^{\prime} 55 \mathrm{E}$, Fig. 1). The lake is located in a mountainous area in southeastern Norway at $701 \mathrm{~m}$ asl. With a surface area of $4.8 \mathrm{~km}^{2}$, it is the largest lake in the River Atna watershed. Maximum and mean depth of the lake is $80 \mathrm{~m}$ and $35.4 \mathrm{~m}$, respectively. The retention time of the lake is about 6 months. $85 \%$ of the catchment of the lake (457 $\mathrm{km}^{2}$ ) is above the tree line, which is at approximately 1000 $\mathrm{m}$ asl. The catchment consists mainly of feldspar quartzite, with large deposits of quaternary and fluvial materials in some areas. There are no glaciers in the catchment, but during cold summers patches of snow remain and affect the temperature of the lake. The Atna watershed and Lake Atnsjøen are little affected by human activities. The area where Lake Atnsjøen is located has a continental climate. The 1961-1990 mean annual temperature and precipitation were $0.7^{\circ} \mathrm{C}$ and $524 \mathrm{~mm}$, respectively. Normally, snow cover lasts from November to early May, and ice cover on the lake lasts from late November to late May. The lake is weakly stratified in summer, with a thermocline usually situated at about $10 \mathrm{~m}$ depth (Halvorsen, 2004).

\section{Sampling}

Zooplankton was sampled in the deepest part of Lake Atnsjøen monthly from June 2010 to October 2011, except for March 2011 due to very low temperatures (Fig. 1). Water transparency was measured with a Secchi disk, and temperature was measured with an YSI ProODO ${ }^{\mathrm{TM}}$ instrument. Sampling and counting of phytoplankton and zooplankton followed procedures for the long term monitoring program in Lake Atnsjøen, described in detail by Brettum and Halvorsen (2004) and Halvorsen et al. (2004). Phytoplankton were analyzed from integrated samples over the top 0 to $10 \mathrm{~m}$ of the water column. The integrated water sample was obtained by sampling consecutive water layers ( 0 to $2 \mathrm{~m}, 2$ to $4 \mathrm{~m}, 4$ to $6 \mathrm{~m}, 6$ to 8 $\mathrm{m}$, and 8 to $10 \mathrm{~m}$ ) with a two-meter tube sampler (diameter $5.2 \mathrm{~cm}$ ) and mixing the water samples in a clean container. The phytoplankton samples were fixed with Lugol's solution. Phytoplankton biovolume were converted to $\mathrm{C}$ using the formula: $\mathrm{C}$ biomass $=0.12$ biovolume $^{1.05}$ (Rocha and Duncan, 1985). The concentration of total organic carbon (TOC) was measured from the integrated 0-10 $\mathrm{m}$ water samples, according to standard procedures (Standards Norway, 1987). The particulate organic carbon (POC) constitutes $11 \%$ of the TOC pool in Lake Atnsjøen (Woszczyk and Jensen, personal communication). The concentration of non-phytoplankton and non-zooplankton particulate dead organic matter was estimated using this percentage and subtracting the phyto- 
plankton and zooplankton fraction of the POC pool. Quantitative zooplankton samples where obtained using a 14-liter Schindler water sampler at $0,1,2,4,6,8,10$, $15,20,30$ and $50 \mathrm{~m}$ depth, with five replicates per depth stratum. These samples were filtered through a $45 \mu \mathrm{m}$ mesh. The quantitative zooplankton samples were supplemented with zooplankton net hauls (diameter $30 \mathrm{~cm}$, length 1 meter, mesh size $45 \mu \mathrm{m}$ ) for length measurements. Zooplankton samples were preserved with Lugol's solution. Enumeration of zooplankton samples is described by Halvorsen et al. (2004).

Zooplankton abundance (ind. $\mathrm{L}^{-1}$ ) was calculated from the quantitative samples and adjusted for the relative contribution of the volume of each depth layer of the lake, taking into account the bathymetry of the lake (Halvorsen et al., 2004). Dry masses of each taxa were calculated, following Bottrell et al. (1976) and Dumont et al. (1975), using fixed mean masses for rotifer species and copepod nauplii and species-specific length-dry mass regressions for cladocerans and copepodites/adult copepods. Length measurements were collected on a representative subsample of 20 individuals of each species from each sampling date. The zooplankton biomass was then calculated by multiplying the zooplankton abundances with the individual dry masses. Zooplankton biomasses, as dry mass, were converted to $\mathrm{C}$ assuming a $\mathrm{C}$ content of $46 \%$ (An- dersen and Hessen, 1991). The phytoplankton:zooplankton biomass ratio were calculated for each sampling date as the ratio between the epilimnetic phytoplankton biomass (by volume) and the whole water-column zooplankton biomass (by volume). This approach likely biased the data towards higher ratios than if the entire water column was considered for phytoplankton, because phytoplankton would be less abundant at greater depths.

\section{Data analysis}

Gridded $\left(1 \mathrm{~km}^{2}\right)$ monthly temperature and precipitation data interpolated from surrounding weather stations provided by the Norwegian Meteorological Institute (Mohr, 2008 , 2009) were compared qualitatively with the 19611990 averages for the respective monthly means (Nordli and Grimenes, 2004). Ice data was obtained from the Norwegian Water Resources and Energy Directorate. Ice-on and ice-off dates were taken as the dates when the whole lake was ice-covered or ice-free. Correlation analysis (Pearson's correlation, r) was used to evaluate relationships between environmental variables. For seasonal studies, a time lag between variables is common. Hence, for environmental variables (daylength, water temperature, Secchi depth and phytoplankton biomass) measurements at the previous census point (t-1) were included in the correlation matrix.
A

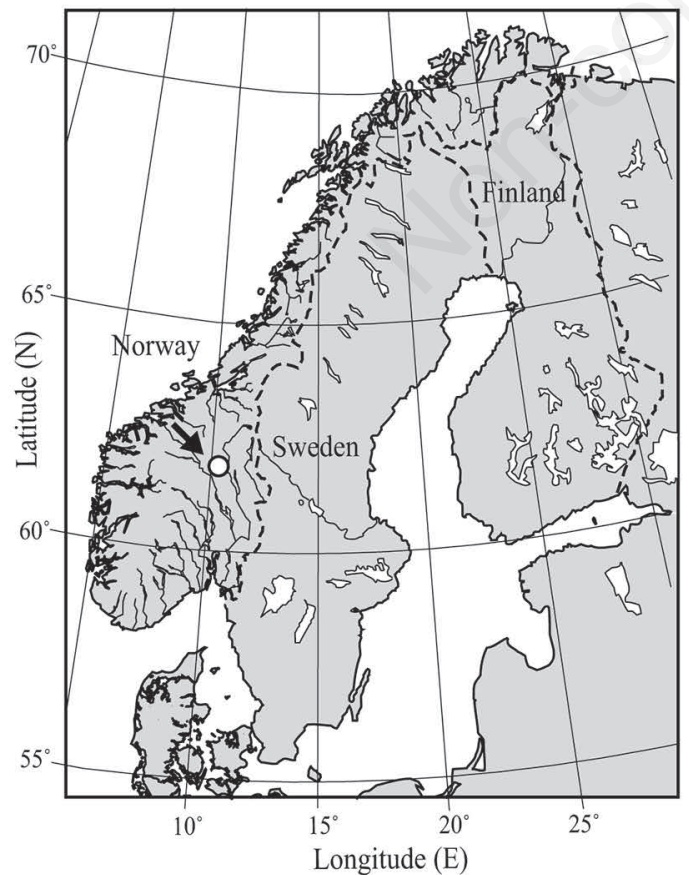

B

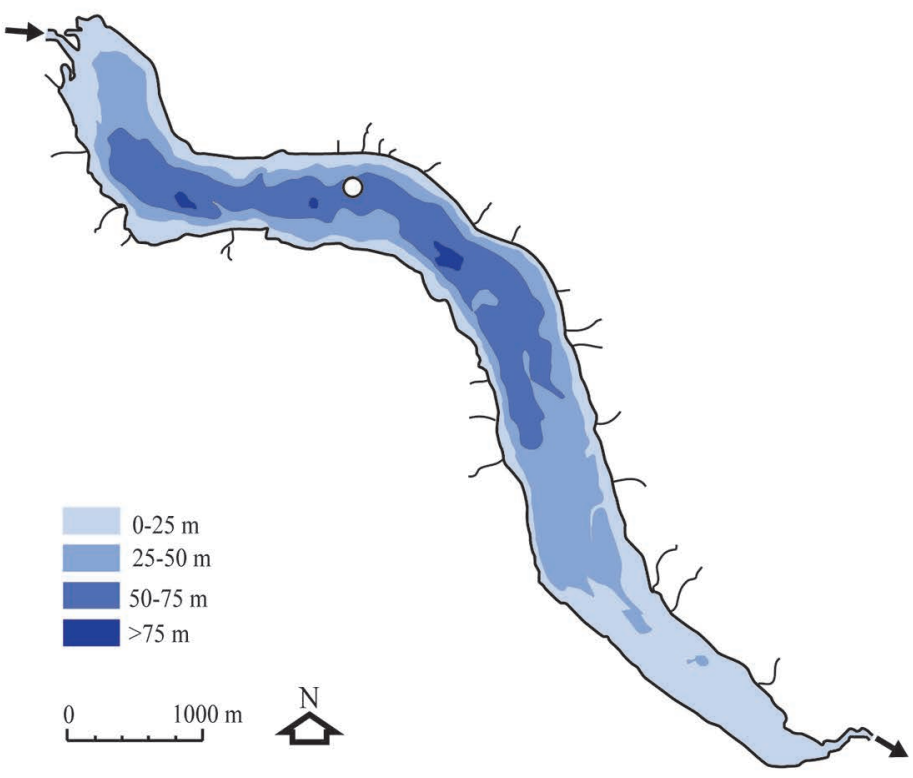

Fig. 1. Map of Scandinavia with the location of Lake Atnsjøen (A, white circle) indicated. Map of Lake Atnsjøen with sampling site indicated (B, white circle). Also indicated is inlet and outlet river (black arrows), and depth contours (blue shading). 
Holm Bonferroni correction were used to adjust for multiple comparisons (Holm, 1979). The mean weighted average water temperature of the water column was used in the statistical analysis. Visual inspection of the residuals of the environmental variables confirmed normal distributions. Differences in biological responses between the growing seasons of 2010 and 2011 and the ice-covered period were visualized by boxplots grouped by season.

The relationships between water temperature and phytoplankton biomass and zooplankton abundance and biomass in Lake Atnsjøen were analyzed using unconstrained and constrained ordination techniques. Initially, principal components analysis (PCA) was used to explore the variation in zooplankton abundance and biomass and to estimate gradient length. To identify possible relationships between zooplankton abundance and biomass and water temperature and phytoplankton biomass (at $\mathrm{t} 1$ and $\mathrm{t}-1$ ) the constrained ordination technique redundancy analysis (RDA, ch. Økland, 1990) were applied due to short gradients. A "minimal adequate model" was developed by forward selection of environmental variables with a Monte Carlo test (499 permutations). Only variables that made significant independent contributions to zooplankton abundance/biomass ( $\alpha=0.05$ level) were included in the model. Multicollinearity of the environmental variables was assessed by checking their Variance Inflation Factors (VIF) using a limit of VIF $>10$ to exclude variables (Borcard et al., 2018). All environmental variables had VIFs below this limit and were thus included in the analysis. To address the unique and shared effects of water temperature and phytoplankton biomass on zooplankton abundance and biomass, respectively, two variance partitioning analysis' (VPA) were conducted using partial redundancy analysis (Borcard et al., 1992). This technique may be used to divide variation in ecological data sets between environmental variables (or groups of environmental variables, Liu, 1997). The water temperature at $t$ and t-1 were grouped together in the analysis. The same was done for phytoplankton biomass. In VPA, the total variation and the unique contribution of the variables and their joint effects are obtained in several steps. For further description of this method, see for example Liu (1997). Environmental variables were kept untransformed in the correlation analysis, as well as in the ordination analysis. Rotifer, cladoceran and copepod abundance and biomass were transformed $(\log 10(\mathrm{x}+1))$ for the analysis. Statistical analyses were conducted in SPSS Statistics 24 (IBM, 2017) and CANOCO 5.0 (Ter Braak and Šmilauer, 2012).

\section{RESULTS}

\section{Weather conditions}

The daylength at Lake Atnsjøen varies between approx. 5 hours in December and 19.5 hours in June (Tab. 1). Average air temperatures at the lake ranged from $-18.0^{\circ} \mathrm{C}$ (Fig. 2 , December 2010) to $13.6^{\circ} \mathrm{C}$ (July 2010). The temperature stayed above $0^{\circ} \mathrm{C}$ from June 2010-October 2010, and again during April 2011-October 2011. The air temperature dur-

Tab. 1. Daylength (Dayl), ice cover and snow cover, average weighted water temperature of the water column ( 0 to $80 \mathrm{~m})$, and total carbon concentration (TOC, incomplete for four sampling dates), on the different sampling days.

\begin{tabular}{|c|c|c|c|c|c|c|}
\hline Date & Day & $\begin{array}{c}\text { Dayl } \\
\text { (hours) }\end{array}$ & $\begin{array}{c}\text { Ice cover } \\
\text { (cm) }\end{array}$ & $\begin{array}{c}\text { Snow cover } \\
(\mathrm{cm})\end{array}$ & $\begin{array}{l}\text { Water temp } \\
\left({ }^{\circ} \mathrm{C}\right)\end{array}$ & $\begin{array}{c}\text { TOC } \\
\left(\mathrm{mg} \mathrm{C} \mathrm{L}^{-1}\right)\end{array}$ \\
\hline 11.06 .2010 & 162 & 19.50 & - & - & 5.0 & - \\
\hline 06.07 .2010 & 187 & 19.28 & - & - & 6.2 & 2.0 \\
\hline 17.08 .2010 & 229 & 15.78 & - & - & 7.0 & - \\
\hline 08.09 .2010 & 251 & 13.65 & - & - & 6.6 & 1.5 \\
\hline 15.10 .2010 & 288 & 10.07 & - & - & 5.4 & - \\
\hline 03.11 .2010 & 307 & 8.23 & - & - & 4.0 & - \\
\hline 14.12 .2010 & 348 & 5.30 & 40 & 10 & 3.3 & 3.5 \\
\hline 26.01 .2011 & 26 & 7.07 & 55 & 50 & 3.3 & 2.2 \\
\hline 28.02 .2011 & 59 & 10.22 & 65 & 35 & 3.3 & 1.6 \\
\hline 12.04 .2011 & 102 & 14.45 & 60 & 5 & 3.3 & 1.8 \\
\hline 11.05 .2011 & 131 & 17.26 & - & - & 4.1 & 2.1 \\
\hline 06.06 .2011 & 157 & 19.27 & - & - & 4.9 & 2 \\
\hline 05.07 .2011 & 186 & 19.35 & - & - & 6.4 & 2.7 \\
\hline 12.08 .2011 & 224 & 16.28 & - & - & 6.9 & 2.3 \\
\hline 06.09 .2011 & 249 & 13.87 & - & - & 7.3 & 1.8 \\
\hline 12.10 .2011 & 285 & 10.38 & - & - & 6.3 & 1.7 \\
\hline
\end{tabular}


ing the 2010 and 2011 growing seasons was slightly above the average (1961-1990), whereas winter 2010/2011 was colder than average. Also, April 2011 was warmer than average. Variation in precipitation followed the same pattern as for temperature, with highest precipitation during JuneAugust both in 2010 and 2011 (Fig. 2, reaching $43.9 \mathrm{~mm}$ in August 2010 and $55.8 \mathrm{~mm}$ in July 2011). Precipitation was below average during the entire study period (Fig. 2). The lake was ice-covered from November 15, 2010. This was relatively early, as average ice-on is November 25 (period 1954-2011). The lake was ice-free again from May 8 , 2011. This was also relatively early. Average ice-off is May 24 (period 1954-2011) and in 2010 it was May 22. The icecovered period lasted for 174 days during the winter 2010/2011. Average ice-covered period was 181 days (period 1954-2011). The date for ice-on in 2011 was relatively late on December 5. Ice thickness in winter 2010/2011 varied between $40 \mathrm{~cm}$ in December and $65 \mathrm{~cm}$ in February (Tab. 1). The snow cover on the ice was rather patchy at times and varied between 5 (April) and $50 \mathrm{~cm}$ (January) at the sampling location (Tab. 1). The temperature data indicated that the winter 2010/2011 was colder than average. However, due to the warm April, spring came early as indicated by the early ice-off date.

\section{Water temperature, Secchi depth and phytoplankton biomass}

The relative weak summer temperature stratification of Lake Atnsjøen was apparent in both 2010 and 2011 (Tab. 1, Fig. 3). Warming of the upper water layers started before the first sampling date (June 11, 2010) and as the summer progressed a weak thermocline developed around $10 \mathrm{~m}$. August 2010 had the highest surface temperatures $\left(14.2^{\circ} \mathrm{C}\right)$ measured. Cooling of the epilimnion started in September 2010 and continued in October. The autumn overturn occurred in the beginning of November, when the whole water column had a temperature of $4^{\circ} \mathrm{C}$. The minimum surface temperature was measured at the end of February $2011\left(0.2^{\circ} \mathrm{C}\right)$. Warming of the surface layers started under the ice in March and April, leading to the spring overturn immediately after ice-off in the beginning of May. The surface water temperatures in summer 2011 was lower than in 2010 (maximum in 2011 was $12^{\circ} \mathrm{C}$ in August), explaining the somewhat weaker thermocline in 2011 (Fig. 3). The autumn overturn in 2011 had not taken place at the last sampling date (October 12). The average water temperature did not differ significantly between the growing season of 2010 and $2011 \quad(t=-0.363, d f=10$, $\mathrm{P}=0.724)$. The Secchi-depth varied between $5.9 \mathrm{~m}$ (July 2011 ) and $8.6 \mathrm{~m}$ (December 2010), and was generally lower during the open water period than during winter (Fig. 4). Furthermore, it was lower in late spring/early summer than later in summer/early autumn.

The phytoplankton concentration in Lake Atnsjøen varied between $2.1 \mu \mathrm{g} \mathrm{C} \mathrm{L}^{-1}$ (end of January 2011) and 36.8 $\mu \mathrm{g} \mathrm{C} \mathrm{L}^{-1}$ (beginning of June 2011, Fig. 4A). The maximum concentration in both 2010 and 2011 occurred in the beginning of June. In addition to this primary peak, 2010 had a secondary phytoplankton peak in September. The concentration was low during winter, until late March/beginning

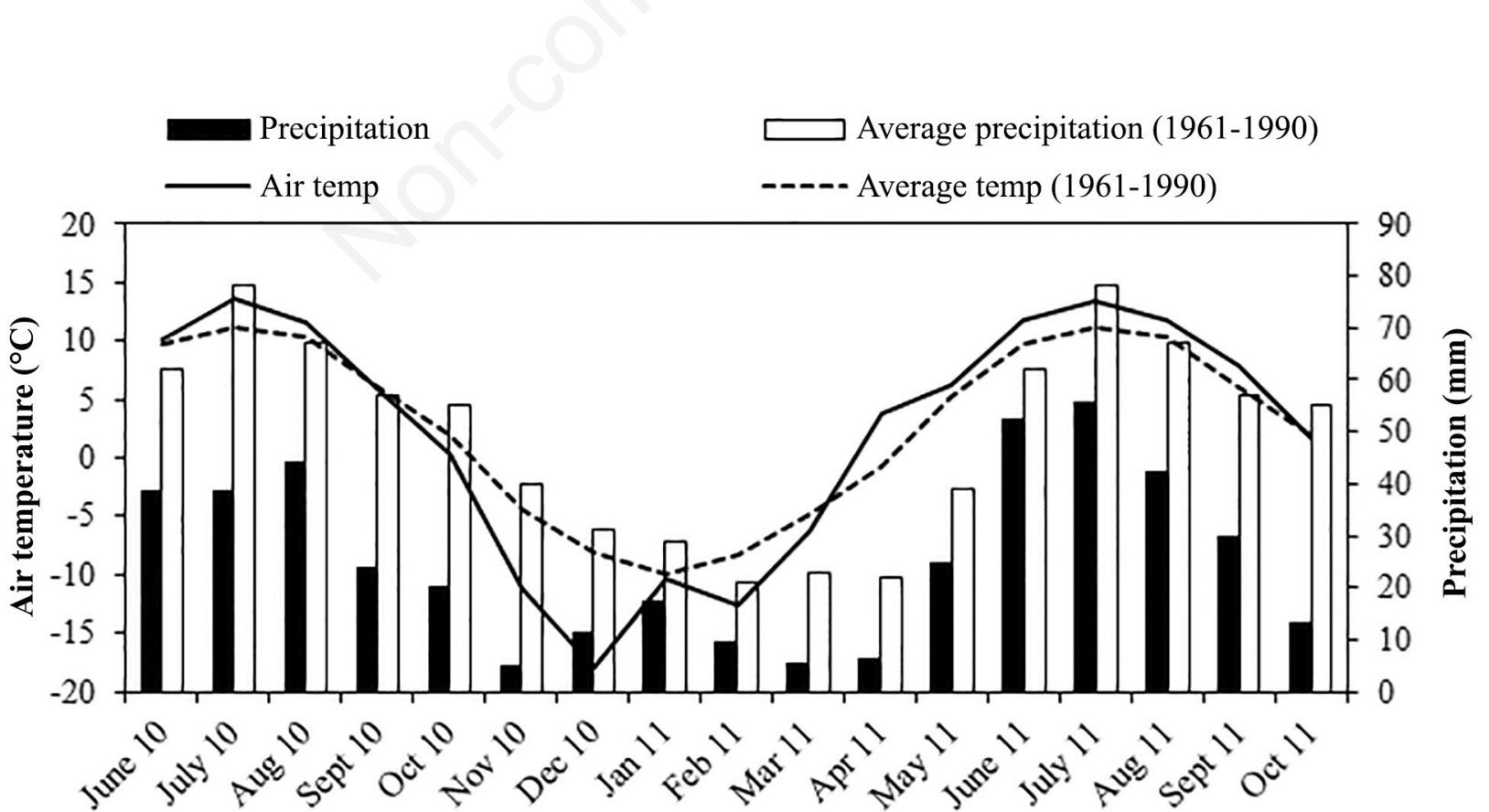

Fig. 2. Monthly average air temperature and precipitation at Lake Atnsjøen in the study period. Also included are the 1961-1990 average taken from Nordli and Grimenes (2004). 
of April when the concentration rose and almost reached the level of the preceding growing season.

The average phytoplankton biomass during the open water seasons of 2010 and 2011 were 2.8 and 3.5 times higher, respectively, than during winter (Fig. 5A). Average and maximum biomass during the open water period in 2011 were both 1.4 times higher than in 2010 . There was a strong correlation between daylength and phytoplankton biomass, and a somewhat weaker, yet significant, correlation between water temperature ${ }_{\mathrm{t}-1}$ and phytoplankton biomass (Tab. 2).

On average, phytoplankton constituted only $10 \%$ of the non-zooplankton POC and from December to February this fraction was much lower (Fig. 4B). The share was highest during the 2011-springbloom in June (20\%). The dependency of the seasonal succession of the lake environment on the changes in day length was illustrated by the correlation of water temperature ${ }_{t-1}$, Secchi depth, and phytoplankton biomass with day length (Tab. 2).

\section{Zooplankton abundance and biomass}

The composition of the zooplankton community was dominated by the cladocerans Daphnia longispina, Bosmina longispina, and Holopedium gibberum, the cyclopoid Cyclops scutifer and the calanoid Arctodiaptomus laticeps. Polyarthra vulgaris, $P$. remata, and Kellicottia longispina dominated the rotifer community. With an average of 11 species the rotifers were the most species rich group. Corresponding values for cladocerans and copepods were 4 and 2 respectively. Rotifer abundance varied between five ind. $\mathrm{L}^{-1}$ (February 2011, Fig. 6) and 435 ind. $\mathrm{L}^{-1}$ (August 2011), and they constituted the largest part of the total zooplankton abundance. In comparison, rotifers accounted for the smallest part of the zooplankton biomass. The rotifer biomass varied between $16.2 \mu \mathrm{g} \mathrm{C} \mathrm{L}^{-1}$ (August 2011) and 0.19 $\mu \mathrm{g} \mathrm{C} \mathrm{(February} \mathrm{2011).} \mathrm{Cladocera}$ abundance varied between 0.6 ind. $\mathrm{L}^{-1}$ (April 2011) and 17 ind. $\mathrm{L}^{-1}$ (June 2010, Fig. 6). While they constituted the smallest part of total zooplankton abundance, total zooplankton biomass was dominated by cladocerans. They varied between $1.3 \mu \mathrm{g} \mathrm{C} \mathrm{L}^{-1}$ (April 2011) and 49.6 $\mu \mathrm{g} \mathrm{C}$ $\mathrm{L}^{-1}$ (July 2011). Copepods constituted a larger fraction of the total zooplankton abundance than the cladocerans, and varied between 10 ind. L ${ }^{-1}$ (August 2011) and 40 ind. $\mathrm{L}^{-1}$ (April 2011). During the copepod peak in April, they constituted the major part of the total zooplankton abundance. This late winter peak in copepod abundance was caused by an increase in nauplii. The copepod biomass varied be-

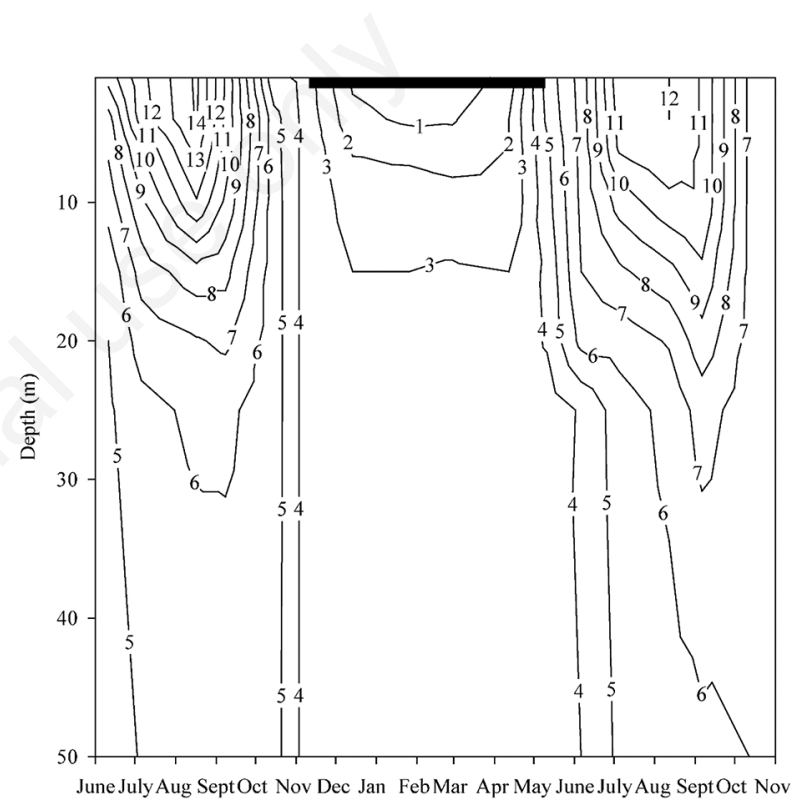

Fig. 3. Isopleth diagrams of water temperatures in Lake Atnsjøen from June 2010-October 2011. The black horizontal bar indicates the winter (ice-covered) period.

Tab. 2. Correlation matrix (r) for environmental variables in Lake Atnsjøen for the period June 2010-October 2011: Daylength, daylength at previous census point (Daylength $\mathrm{t}_{\mathrm{t}-1}$ ), average water temperature of the water column $(\mathrm{Wt})$, average water temperature of the water column at previous census point $\left(\mathrm{Wt}_{\mathrm{t}-1}\right)$, Secchi depth (Secchi), Secchi depth at previous census point $\left(\right.$ Secchi $\left.{ }_{\mathrm{t}-1}\right)$, phytoplankton biomass (Phyto), phytoplankton biomass at previous census point $\left(\mathrm{Phyto}_{\mathrm{t}-1}\right)$.

\begin{tabular}{|c|c|c|c|c|c|c|c|c|}
\hline & Daylength & Daylength $_{t-1}$ & Wt & $\mathbf{W t}_{\mathrm{t}-1}$ & Secchi & Secchi $i_{t-1}$ & Phyto & Phyto $_{t-1}$ \\
\hline Daylength & 1 & & & & & & & \\
\hline Daylength $_{t-1}$ & $0.829^{*}$ & 1 & & & & & & \\
\hline $\mathrm{Wt}$ & 0.472 & $0.836^{*}$ & 1 & & & & & \\
\hline $\mathrm{Wt}_{\mathrm{t}-1}$ & 0.038 & 0.530 & $0.835^{*}$ & 1 & & & & \\
\hline Secchi & $-0.793^{*}$ & $-0.754 *$ & -0.461 & -0.124 & 1 & & & \\
\hline Secchi $_{t-1}$ & -0.627 & $-0.814 *$ & $-0.744 *$ & -0.469 & 0.419 & 1 & & \\
\hline Phyto & $0.860^{*}$ & $0.765^{*}$ & 0.487 & 0.200 & -0.675 & -0.536 & 1 & \\
\hline Phyto $_{t-1}$ & 0.664 & $0.873 *$ & $0.762 *$ & 0.502 & -0.684 & -0.675 & 0.589 & 1 \\
\hline
\end{tabular}

*Correlation was significant at the 0.05 level (Holm Bonferroni correction for multiple comparisons). 
tween $1.9 \mu \mathrm{g} \mathrm{C} \mathrm{L}^{-1}$ (February 2011) and $34.2 \mu \mathrm{g} \mathrm{C} \mathrm{\textrm {L } ^ { - 1 }}$ (July 2011). Total zooplankton abundance varied between 19 ind. $\mathrm{L}^{-1}$ (February 2011) and 449 ind. L L $^{-1}$ (August 2011). Minimum total zooplankton biomass was $4.3 \mu \mathrm{g}$ $\mathrm{C} \mathrm{L}^{-1}$ (February 2011) and maximum was $85.9 \mu \mathrm{g} \mathrm{C} \mathrm{L}^{-1}$ (July 2011).

The average abundance and biomass of rotifers were considerable higher during the growing season compared to winter (Fig. 5 B,F). Rotifer abundances were 4.9 and 13.8 times higher during the 2010 and 2011 open water periods, respectively, than during winter. For rotifer biomass the corresponding values were 5.7 and 13.6. Cladoceran abundance and biomass were also substantially higher during the growing season compared to winter (Fig. 5 C,G). Cladoceran abundances were 5.3 and 4.6 times higher, during the 2010 and 2011 open water peri-
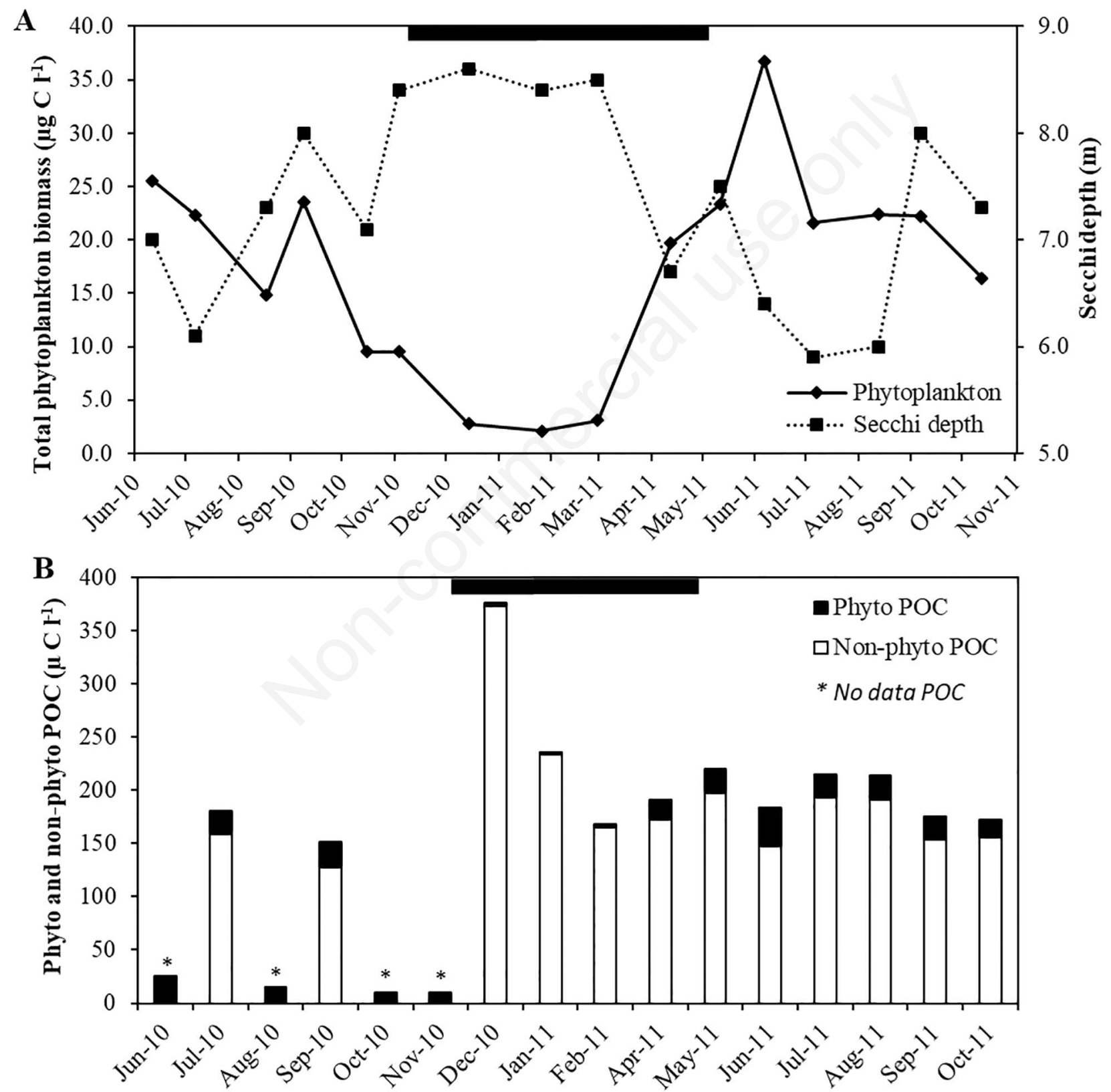

Fig. 4. Phytoplankton biomass and Secchi depth (upper panel) in Lake Atnsjøen from June 2010-October 2011. Non-phytoplankton particulate organic carbon (Non-phyto POC) compared to the phytoplankton fraction of POC (phyto POC, lower panel). See methods for description of calculation of POC. The black horizontal bars indicate the winter (ice-covered) period. 
ods, respectively, than during winter. For cladoceran biomass the corresponding values were 5.0 and 6.1. Though, average copepod abundance was slightly lower during the growing season compared to winter $(0.8$ for open water period in 2010 compared to winter and 0.9 for open water period 2011 compared to winter, Fig. 5D), copepod biomass showed similar pattern as rotifer and cladoceran biomass (2.6 for open water period in 2010 compared to winter and 4.3 for open water period 2011 compared to winter, Fig. 5H). Finally, average total zooplankton abundance and biomass was also considerable higher during the open water period than during winter (Fig. 5 E,I). Total zooplankton abundance were 2.1 and 4.7 times higher during the 2010 and 2011 growing seasons, respec- tively, than during winter. For total zooplankton biomass the corresponding values were 3.7 and 5.5.

Due to the very high rotifer abundance in august 2011, average and maximum total zooplankton abundance during the open water period of 2011 was 2.2 and 4.8 times higher, respectively, than during the 2010 open water period (Fig. 5E). Average biomass of all zooplankton groups, as well as average total zooplankton biomass, was also slightly higher during the 2011 open water period than during the 2010 open water period (Fig. 5 F-I). The differences were greater for peak zooplankton biomass estimates. The timing of and number of peaks for rotifer and copepod biomass during the growing season were similar for 2010 and 2011 with rotifer maximum in august and
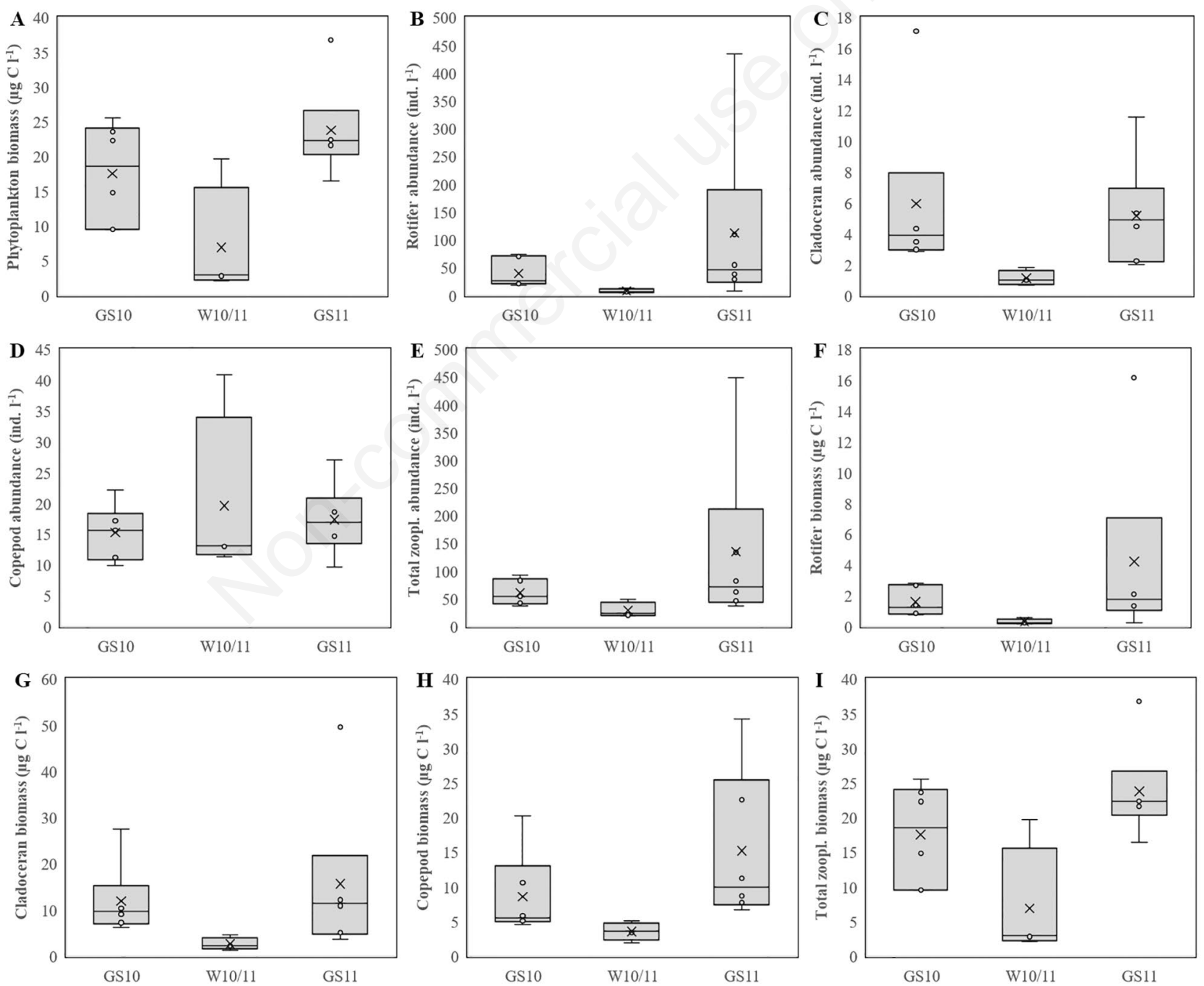

Fig. 5. Boxplots grouped by season (GS10, growing season of 2010; W10/11, ice-covered period 2010/2011; GS11, growing season 2011), showing median, mean, minimum, first quartile, third quartile, maximum, and outliers of phytoplankton biomass (A), rotifer abundance (B), cladoceran abundance (C), copepod abundance (D), total zooplankton abundance (E), rotifer biomass (F), cladoceran biomass $(\mathrm{G})$, copepod biomass $(\mathrm{H})$, and total zooplankton biomass (I). Mean and outliers are indicated by "x" and "o" respectively. 
copepod maximum in June (2010)/July (2011). For comparison, the number of cladoceran biomass peaks differed between the two growing seasons. Maximum cladoceran biomass was reached in July both years. However, 2010 had a secondary smaller peak in October. The development of the total zooplankton biomass followed the same pattern as the cladoceran biomass.

The PCA indicated that the seasonal variation in zooplankton abundance was mainly determined by changes in rotifer abundance (Fig. 7A). The first two RDA axes in the constrained ordination of zooplankton abundance had eigenvalues of 0.641 and 0.071 , respectively (Fig. $7 \mathrm{~B})$. The environmental variables accounted for $72.6 \%$ of the variation in zooplankton abundance (adjusted explained variation $61.6 \%$ ). There was a significant relationship between the set of environmental variables and zooplankton abundance (i.e. all canonical axes, F-ratio $=6.6, \mathrm{P}=0.002$ ). The "minimal adequate model" included the explanatory variables water temperature ${ }_{\mathrm{t}}$ and phyto-

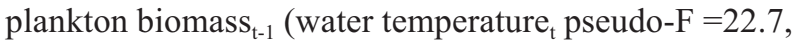
$\mathrm{P}=0.002$; phytoplankton biomass $_{\mathrm{t}-1}$ pseudo-F $=2.9$, $\mathrm{P}=0.042$ ). Rotifer abundance was most strongly corre-

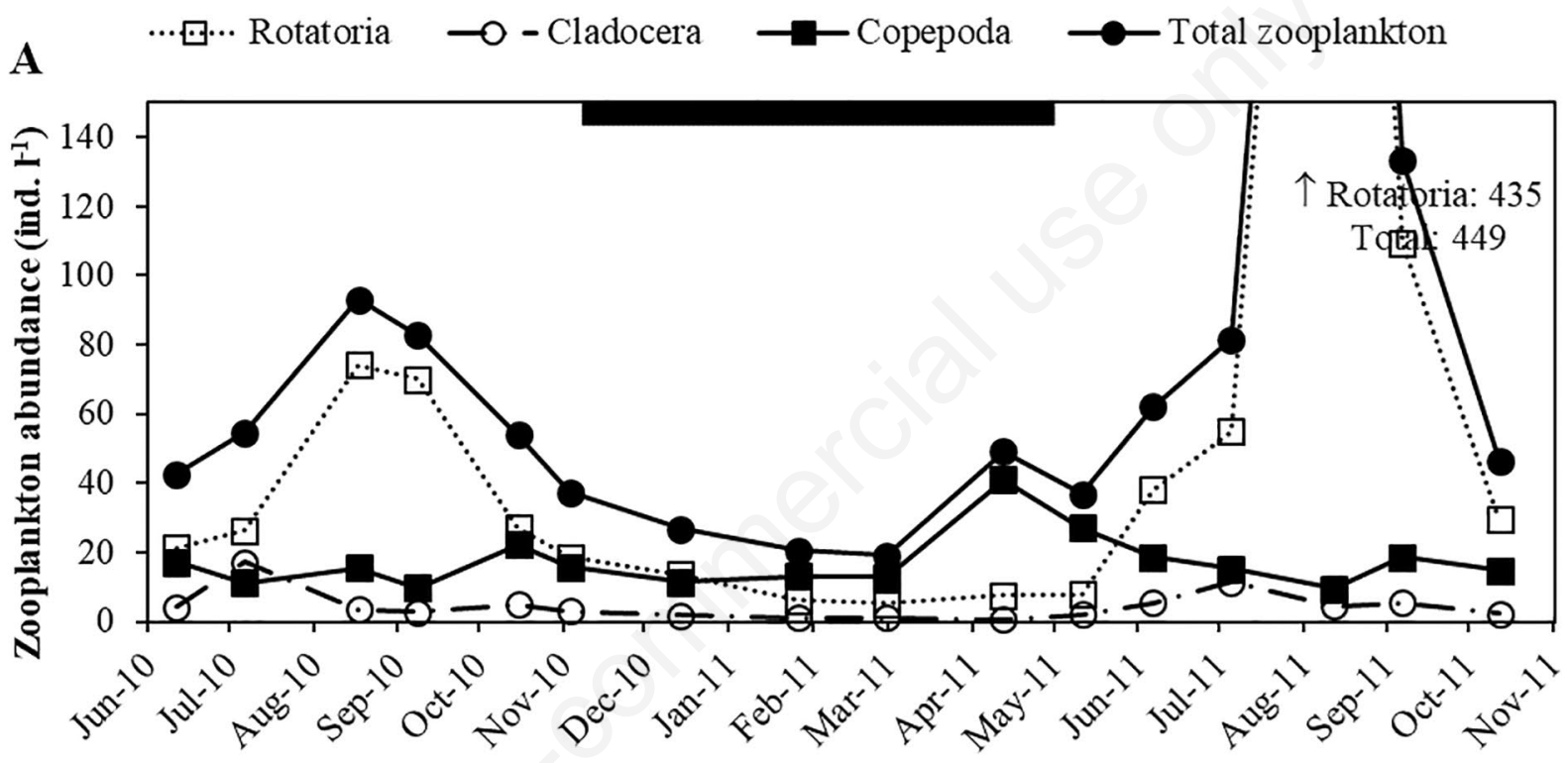

B

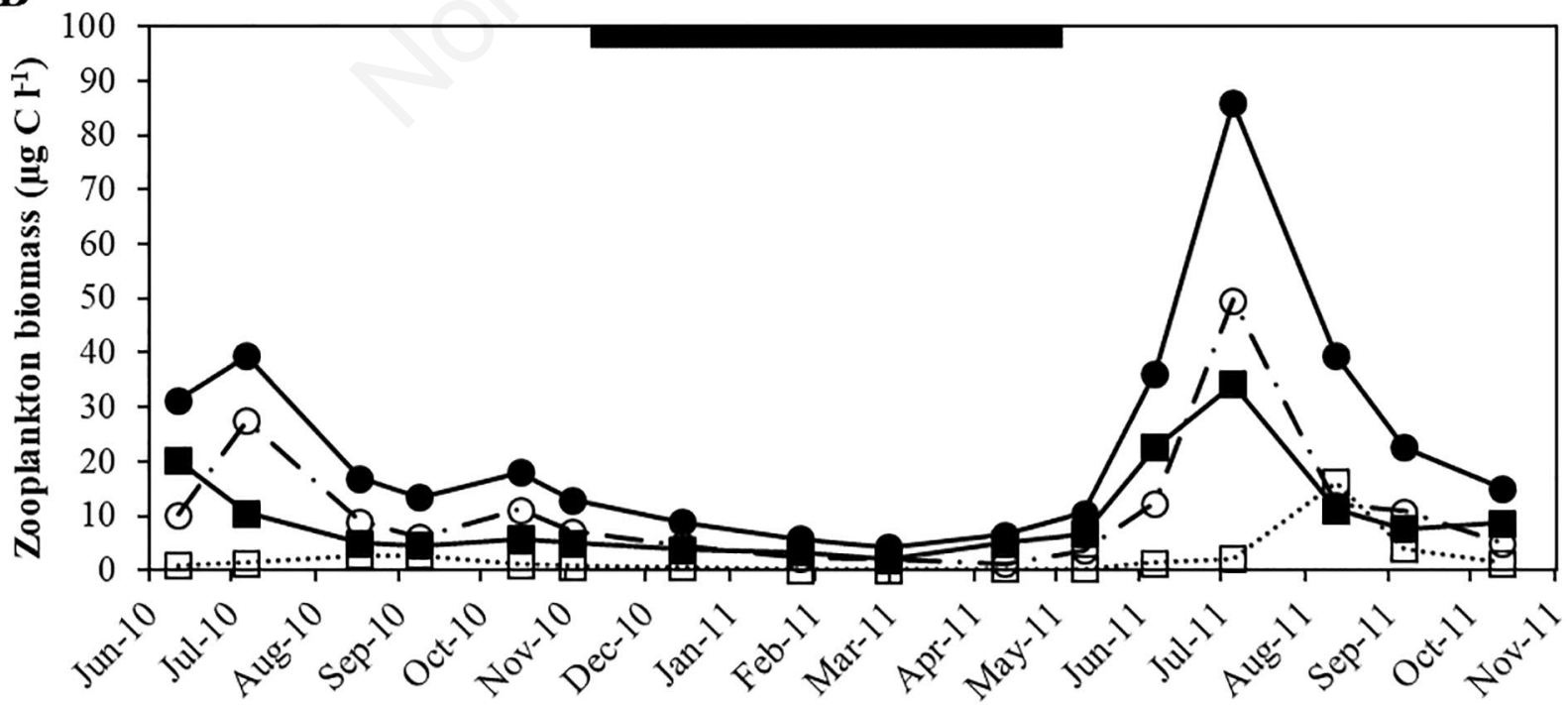

Fig. 6. Zooplankton abundance (A) and biomass (B) in Lake Atnsjøen from June 2010-October 2011. The black horizontal bars indicate the winter (ice-covered) period. 
lated with water temperature, while cladoceran abundance was more closely related to phytoplankton biomass. The seasonal variation in zooplankton biomass was mainly due to changes in cladoceran and copepod biomass (Fig. 7C). In the constrained RDA of zooplankton biomass the first two axes had eigenvalues of 0.615 and
0.133 , respectively (Fig. 7D). The environmental variables accounted for $77.6 \%$ of the variation in zooplankton biomass (adjusted explained variation $68.6 \%$ ). There was a significant relationship between the set of environmental variables and zooplankton biomass (i.e., all canonical axes, F-ratio $=8.6, \mathrm{P}=0.002$ ). The same ex-
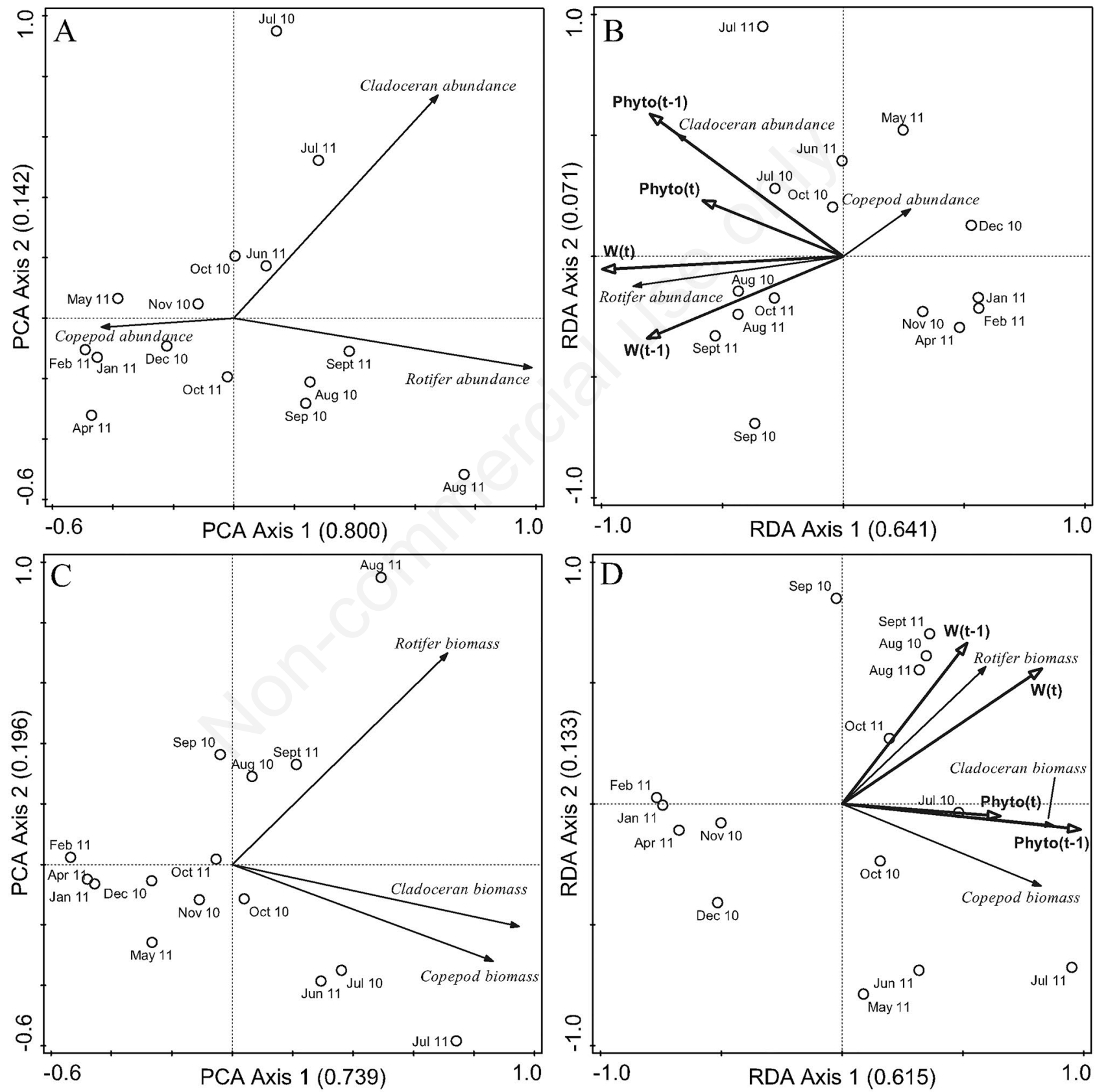

Fig. 7. Results from the ordination analysis of zooplankton abundance and biomass in Lake Atnsjøen during the period June 2010 October 2011. PCA biplot of zooplankton abundance (A). RDA triplot of zooplankton abundance (B), environmental variables included are water temperature and phytoplankton biomass at $t$ and $t-1$, eigenvalues are given in brackets on the axes. PCA biplot of zooplankton biomass (C). RDA triplot of zooplankton biomass (D), environmental variables and eigenvalues as in B. 
planatory variables were included in the minimal adequate model for zooplankton biomass (phytoplankton biomass $_{\mathrm{t}-1}$ pseudo- $\mathrm{F}=19.5, \mathrm{P}=0.002$; water temperature $_{\mathrm{t}}$ pseudo- $\mathrm{F}=6.3, \mathrm{P}=0.002$ ) as for zooplankton abundance. Rotifer biomass was stronger correlated with water temperature, while cladoceran biomass was more correlated to phytoplankton biomass. The variance partitioning analysis indicated that the shared effect of water temperature and phytoplankton biomass explained the largest significant fraction of the total variation in zooplankton abundance, but water temperature alone also had a significant contribution (Tab. 3). Even though the main effect of phytoplankton biomass was not significant it still had to be considered due to the significant shared effect of water temperature and phytoplankton biomass. The shared effect of water temperature and phytoplankton biomass also explained the largest fraction of the total variation in zooplankton biomass and the effect was significant (Tab. 3). Phytoplankton biomass alone explained a larger fraction than water temperature alone, but both contributions were significant. The significant shared effect of water temperature and phytoplankton biomass on the total variation in zooplankton abundance and biomass could be due to the correlation between water temperature and phytoplankton biomass.

The ratio of phytoplankton to zooplankton biomass varied between 0.25 in July 2011 and 2.98 in April 2011 (Fig. 8 ). On 11 out of the 16 sampling dates, the ratio was below 1.0 and on half of the sampling dates the ratio was below 0.8 . During winter, the ratio was typically below 0.8 .

Tab. 3. Results from the variance partitioning analysis of zooplankton abundance and biomass in Lake Atnsjøen. P-values were corrected by the Holm Bonferroni to account for multiple comparisons

\begin{tabular}{|c|c|c|c|c|c|c|}
\hline \multirow[b]{2}{*}{ Fraction } & \multicolumn{3}{|c|}{ Zooplankton abundance } & \multicolumn{3}{|c|}{ Zooplankton biomass } \\
\hline & $\begin{array}{l}\% \text { of } \\
\text { explained }\end{array}$ & $\begin{array}{l}\% \text { of } \\
\text { total }\end{array}$ & $\mathbf{P}$ & $\begin{array}{c}\% \text { of } \\
\text { explained }\end{array}$ & $\begin{array}{l}\% \text { of } \\
\text { total }\end{array}$ & $\mathbf{P}$ \\
\hline Water temperature $\left(\mathrm{W}_{\mathrm{t}}\right.$ and $\left.\mathrm{W}_{\mathrm{t}-1}\right)$ & 37.0 & 26.9 & 0.032 & 18.5 & 14.4 & 0.024 \\
\hline Phytoplankton biomass $\left(\right.$ Phyto $_{\mathrm{t}}$ and $\left._{\text {phyto }} \mathrm{t}_{\mathrm{t}-1}\right)$ & 9.4 & 6.8 & 0.312 & 30.4 & 23.6 & 0.024 \\
\hline $\begin{array}{l}\text { Shared effect of water temperature }\left(\mathrm{W}_{\mathrm{t}} \text { and } \mathrm{W}_{\mathrm{t}-1}\right) \text { and phytoplankton biomass } \\
\left(\text { Phyto }_{\mathrm{t}} \text { and phyto } \mathrm{t}_{\mathrm{t}-1}\right)\end{array}$ & 53.6 & 38.9 & 0.006 & 51.1 & 39.6 & 0.006 \\
\hline Total explained variation & 100 & 72.6 & & 100 & 77.6 & \\
\hline
\end{tabular}

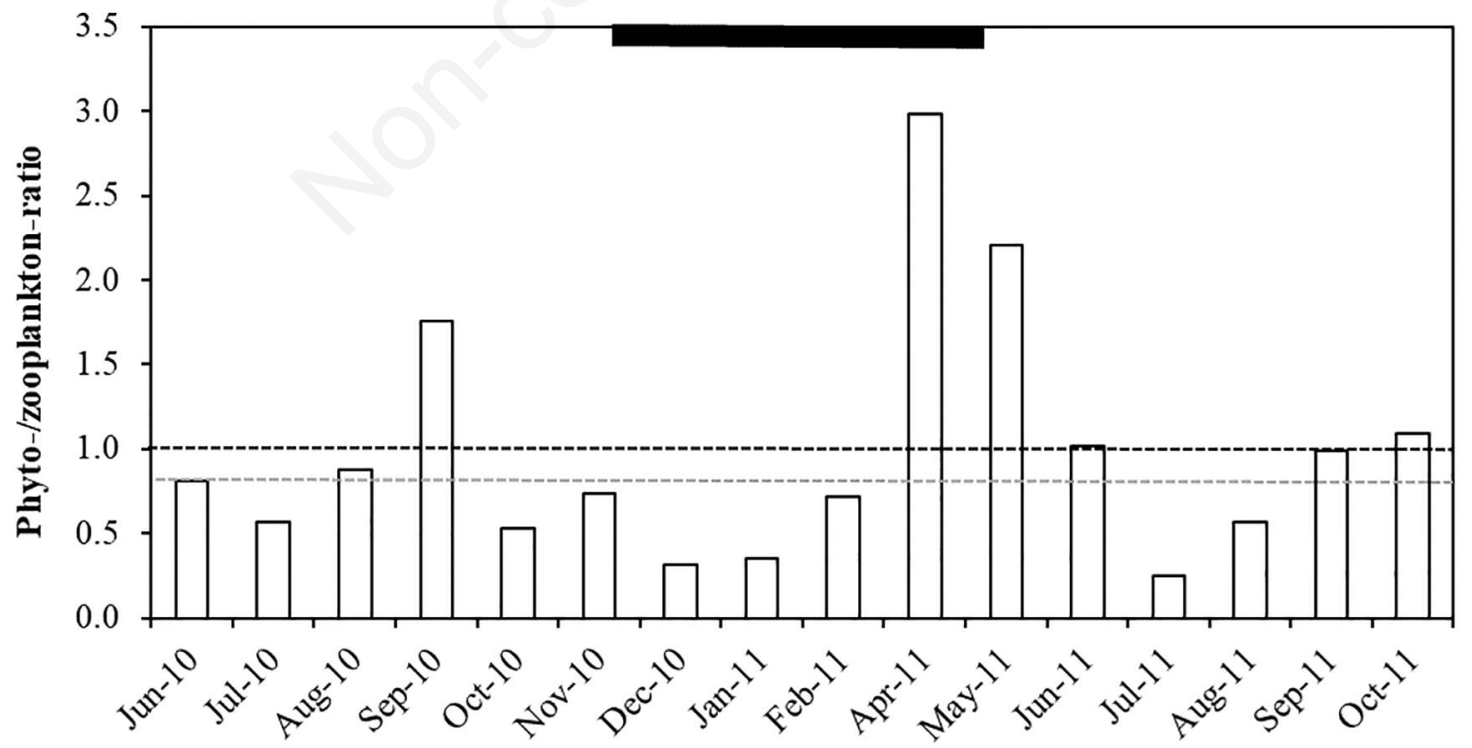

Fig. 8. Phytoplankton:zooplankton biomass ratio (C:C) in in Lake Atnsjøen from June 2010-October 2011. The black dotted horizontal line indicate a phytoplankton:zooplankton biomass ratio of one. The grey dotted horizontal line indicate the primary production to zooplankton biomass ratio of 0.8 needed for zooplankton maintenance estimated by Hessen et al. (2003b). The black horizontal bar indicates the winter (ice-covered) period. 


\section{DISCUSSION}

Information on abundance of metazoan zooplankton under ice is scarce in the literature. The range of crustacean zooplankton abundances reported by Hampton and colleagues (2017) covers the winter average in Lake Atnsjøen. Typically, winter abundance and biomass increase with lake trophic state (Dokulil and Herzig, 2009). However, by including only one winter, the current study does not shed light over annual variability in winter zooplankton abundance and biomass in Lake Atnsjøen. Dokulil and Herzig (2009) note that winter zooplankton may be quite variable from year to year in the same lake, which is likely also the case in Lake Atnsjøen.

Overall, zooplankton abundance and biomass in Lake Atnsjøen were lower in winter than during the growing season. This accords with findings of Hampton et al. (2017). However, average winter copepod abundance did not differ much from average abundances during the open water period, due to the late winter peak in copepod nauplii. As data from other winters are not available for comparison, it is not possible to tell whether this is normal or an outlier occurrence. The revised PEG-model acknowledges the importance of the winter period (Sommer et al., 2012). For example, winter zooplankton populations may exert a substantial grazing pressure on the spring phytoplankton, reducing the spring phytoplankton peak (Sommer et al., 2012). It is becoming increasingly clear that carry-over effects from the winter may affect lake ecology throughout the year and this includes the zooplankton component of the lake ecosystem (Adrian et al., 2006). The 2010/2011 late winter build-up of copepod nauplii concurrent to increasing phytoplankton biomass, kickstarted the copepod population and may have contributed to the higher copepod biomass in 2011 compared to 2010. In Lake Atnsjøen, the winter survival of $C$. scutifer may vary from above $60 \%$ to as little as $6 \%$ (Halvorsen et al., 2004). Such a high variation might be linked to annual variation in ice thickness and snow cover affecting light availability for phytoplankton under the ice as shown in a mountain lake (Obertegger et al., 2017). Variation in winter mortality clearly has consequences for the spring and summer population of C. scutifer in the lake.

Seasonal lake studies of metazoan zooplankton that include the ice-covered period are rare (Larsson, 1978; Larsson et al., 1978; Virro et al., 2009). The average total metazoan biomass in Lake Øvre Heimsdalsvatn (southwestern Norway) for months with ice cover in 1972 (January - early June and late October to December) was approx. $14 \mu \mathrm{g} \mathrm{DW}{ }^{-1}$, corresponding to approx. $7 \mu \mathrm{g} \mathrm{C}$ $\mathrm{L}^{-1}$, (assuming a carbon content of $46 \%$, Andersen and Hessen, 1991). The winter average in Lake Atnsjøen at $6.4 \mu \mathrm{g} \mathrm{C} \mathrm{L}^{-1}$ was similar. The average total metazoan biomass in Øvre Heimsdalvatn during the growing season in
1972 (approx. $19 \mu \mathrm{g} \mathrm{C} \mathrm{L}^{-1}$ ) was somewhat lower than the Lake Atnsjøen 2010 open water average $\left(23.9 \mu \mathrm{g} \mathrm{C} \mathrm{L}^{-1}\right)$ and only half of the 2011 open water average (39.9 $\mu \mathrm{g} \mathrm{C}$ $\mathrm{L}^{-1}$ ). Both lakes are oligotrophic (Kloster, 1978; Halvorsen, 2004). However, due to its higher altitude Lake Øvre Heimdalsvatn has a shorter open-water season than Lake Atnsjøen (Larsson et al., 1978). The summer zooplankton biomass increases with length of the growing season in oligotrophic lakes (Weyhenmeyer et al., 2013). Hence, longer growing season may explain the higher zooplankton biomass in Lake Atnsjøen compared to Lake Øvre Heimsdalsvatn.

The importance of temperature versus phytoplankton biomass for the different zooplankton groups was clearly different. Rotifer abundance and biomass were most strongly related to temperature, while phytoplankton biomass (at t-1) had a stronger impact on cladoceran abundance and biomass, as well as copepod biomass. This difference is likely related to the life history strategies of the three zooplankton groups. Rotifers and cladocerans mainly reproduce parthenogenetically, while copepods have obligate sexual reproduction. Moreover, rotifers have short generation times (Allan, 1976; Walz, 1995; Andersen, 1997; Gillooly, 2000), as well as lower food concentration thresholds (Stemberger and Gilbert, 1985). This life history strategy confers a strong dependency on temperature (Edmondson, 1965). In comparison, cladocerans have longer generation times and higher food concentration thresholds (Allan, 1976; Andersen, 1997). The cladoceran life history strategy is therefore more dependent on resource availability. Copepods have even longer generation times (Allan, 1976; Andersen, 1997), with a life cycle lasting one or two years in Lake Atnsjøen (Halvorsen et al., 2004). Additionally, fish predation on zooplankton may be high in oligotrophic lakes such as Lake Atnsjøen (Jeppesen et al., 2003). Cladocerans suffer higher mortality from fish predation than rotifers and copepods, at least in summer (Saksgård and Hesthagen, 2004). The dominating fishes in Lake Atnsjøen are arctic char (Salvelinus alpinus) and brown trout (Salmo trutta). Although both species utilize crustacean zooplankton (largely cladocerans) as food, char is the most important zooplankton predator in the lake. Char shows a strong preference for larger species such as Daphnia (Saksgård and Hesthagen 2004; Sandlund O.T. et al., personal communication), but also eats some cyclopoid copepods in winter (Nilssen, 1977). Rotifers are not eaten by the fish (Saksgård and Hesthagen, 2004). The fish predation intensity in the pelagic zone in oligotrophic lakes with large char populations typically increases during the summer, peaks in mid/late summer, and declines again in September (Hindar and Jonsson, 1982). Besides resource limitation, increasing fish predation likely also reduced zooplankton biomass after the spring bloom in June. 
Low light levels, ice and snow cover, and cold water contributed to a low phytoplankton biomass in Lake Atnsjøen during the early and mid-winter 2010/2011. With increasing daylength and light availability and decreasing snow cover in April, phytoplankton biomass increased towards the end of winter. A relative high under-ice phytoplankton biomass is not an uncommon phenomenon in temperate and arctic lakes, during late winter when light availability increases (Chandler, 1940; Langeland and Reinertsen, 1982; Forsström et al., 2007). In fact, light is more important than temperature in limiting phytoplankton production in lakes (Winder and Sommer, 2012). The average winter phytoplankton biomass in Lake Atnsjøen was in the upper range of that observed in other ice-covered lakes (Hampton et al., 2017). Except for the late winter bloom, phytoplankton availability to zooplankton was much lower during winter than during the growing season. The fraction of non-phytoplankton POC was much higher than that of phytoplankton POC, as is the case in many nutrient poor Norwegian lakes during the growing season (Hessen et al., 2003a). Furthermore, non-phytoplankton POC in early winter was higher than during the growing season, which was also observed by Rautio et al. (2011) in an oligotrophic subarctic lake.

The current study indicated the close association between zooplankton and phytoplankton biomass, underlining the importance of phytoplankton as an important food resource for zooplankton (Galloway et al., 2014). However, the phytoplankton/zooplankton ratios in summer, autumn, and winter were below zooplankton maintenance requirements (Hessen et al., 2003b). In addition, the prevailing low phytoplankton biomass in the lake was below the threshold food concentrations of many species even during the spring bloom (Andersen, 1997). These findings indicate that the Lake Atnsjøen zooplankton was also dependent on other C-resources. Zooplankton may also utilize autochthonous or allochthonous derived dead POC, either directly or via DOC fueling the microbial loop (Grey et al., 2001; Galloway et al., 2014). The estimates of non-algal POC in Lake Atnsjøen, which include both autochthonous and allochthonous dead POC as well as the components of the microbial loop, indicate that this part of the C-pool was an important potential additional C-sources for the zooplankton. This could be especially true during early and mid-winter, when algal food is very low (Grey et al., 2001; Rautio et al., 2011). However, C requirements of the zooplankton also decrease at this time, due to lower temperatures and because many species enter a dormant phase during winter (Kibby, 1971; Allan, 1976). Another aspect that should be considered is omnivory, both in a strict sense and from an ontogenetic perspective. For example, some Daphnia species are capable of eating smaller zooplankters (Wickham et al., 1993). Cyclops has an ontogenetic shift in feeding mode, with the smaller developmental stages being primarily herbivorous, while larger developmental stages are mainly predacious (Zaret, 1980; Santer, 1993). Hence, for species or stages capable of utilizing smaller zooplankton as food, phytoplankton concentration underestimates food availability.

The current study does not contradict the PEG-model (Sommer et al., 1986; Sommer et al., 2012), however, it exemplifies how the plankton dynamics in oligotrophic lakes may be affected by a changing climate (De Senerpont Domis et al., 2012). Like many other ice-covered lakes, Lake Atnsjøen experiences an increase in the icefree period due to a warmer climate. This is especially caused by a warmer late winter/early spring resulting in an earlier ice-off (Jensen unpublished results). The early ice-off and late ice-on dates in 2011 resulted in an unusually long growing season (ice-free period) of 211 days. This was 26 days longer than the average for the period 1954-2011, and 34 days longer than in 2010. During the period 1954-2011 only two years have seen a longer open water period than 2011. In comparison, $2010 \mathrm{had}$ an open water period shorter than average (1954-2011), mainly due to early ice-on. A longer growing season may lead to higher phytoplankton and zooplankton abundance and biomass in temperate oligotrophic lakes (De Senerpont Domis et al., 2012; Weyhenmeyer et al., 2013). The early onset of the growing season and its long duration in 2011 may have contributed to the somewhat higher phytoplankton biomass and zooplankton abundance/biomass in 2011 than in 2010. For instance, in Müggelsee, Germany, the magnitude of the phytoplankton spring bloom increased with decreasing ice duration (Adrian et al., 1999). Since the current study only represents two open water seasons and the winter period between, it is not possible to draw any conclusion regarding the importance of a prolonged growing season. Lower than average winter precipitation, causing reduced snowpack and potentially greater light penetration in late spring, could also have contributed to kickstart the phytoplankton production resulting in higher phytoplankton and zooplankton biomass during the open water period in 2011. It is intriguing that the difference between the two years in Lake Atnsjøen was larger for zooplankton biomass (and abundance) than for phytoplankton biomass. Phytoplankton productivity may have been higher in 2011 compared to 2010, thus potentially sustaining a higher zooplankton population that kept phytoplankton biomass low. Zooplankton may also have utilized other food sources than phytoplankton, as outlined above. Differences in fish predation regimes on zooplankton between 2010 and 2011 are less likely to explain annual differences in zooplankton biomass, as test fishing in 2010 and 2011 showed very similar fish population size (Hesthagen $\mathrm{T}$. and Saksgård R., personal communication). 


\section{CONCLUSIONS}

In conclusion, the zooplankton abundance and biomass were much lower in winter than during the open water season in oligotrophic subalpine Lake Atnsjøen, with the exception of the final winter months. During the later period snow cover and ice thickness were reduced and (presumably) light penetration increased, leading to an under-ice phytoplankton bloom and an increase in abundance of copepod nauplii. Hence, the study lends support to the view emerging during the last decade, that winter is not only an unimportant period of dormancy (Salonen et al., 2009; Sommer et al., 2012; Bertilsson et al., 2013; Hampton et al., 2015). The somewhat higher phytoplankton and zooplankton abundance and biomasses in 2011, with earlier ice-off and longer growing season compared to 2010, also hint to some of the expected changes of climate change on northern lake ecosystems.

\section{ACKNOWLEDGMENTS}

I owe thanks to Edwige Bellier, Anders Finstad, Katarzyna Papinska, Inta Dimante-Deimantovica, and Pål Brettum for help with field work and sample counting, to Stefan Blumentrath for obtaining gridded temperature and precipitation data from the Norwegian Meteorological Institute and to Ånund Kvambekk (Norwegian Water Resources and Energy Directorate) for providing lake ice data. Bror Jonsson, Jon Magerøy, and two anonymous reviewers provided valuable suggestions, comments, and linguistic corrections on the manuscript.

\section{REFERENCES}

Adrian R, Walz N, Hintze T, Hoeg S, Rusche R, 1999. Effects of ice duration on plankton succession during spring in a shallow polymictic lake. Freshwater Biol. 41:621-632.

Adrian R, Wilhelm S, Gerten D, 2006. Life-history traits of lake plankton species may govern their phenological response to climate warming. Global Change Biology 12:652-661.

Allan JD, 1976. Life history patterns in zooplankton. Am. Nat. 110:165-180.

Andersen T, Hessen DO, 1991. Carbon, nitrogen, and phosphorus content of freshwater zooplankton. Limnol. Oceanogr. 36:807-814.

Andersen TO, 1997. Pelagic nutrient cycles: Herbivores as sources and sinks for nutrients. 1. Springer, Berlin: $283 \mathrm{pp}$.

Benson BJ, Magnuson JJ, Jensen OP, Card VM, Hodgkins G, Korhonen J, Livingstone DM, Stewart KM, Weyhenmeyer GA, Granin NGJCC, 2012. Extreme events, trends, and variability in Northern Hemisphere lake-ice phenology (18552005). Clim. Change 112:299-323.

Bertilsson S, Burgin A, Carey CC, Fey SB, Grossart H-P, Grubisic LM, Jones ID, Kirillin G, Lennon JT, Shade A, Smyth
RL, 2013. The under-ice microbiome of seasonally frozen lakes. Limnol. Oceanogr. 58:1998-2012.

Borcard D, Gillet F, Legendre P, 2018. Numerical ecology with R. Springer, New York: 306 pp.

Borcard D, Legendre P, Drapeau P, 1992. Partialling out the spatial component of ecological variation. Ecology 73:1045-1055.

Bottrell HH, Duncan A, Gliwicz ZM, Grygierek E, Herzig A, Allbright-Ilkowska A, Kurasawa H, Larsson P, Weglenska T, 1976. A review of some problems in zooplankton production studies. Norw. J. Zool. 24:419-456.

Brettum P, Halvorsen G, 2004. The phytoplankton of Lake Atnsjøen, Norway - a long-term investigation. Hydrobiologia 521:141-147.

Brooks JL, Dodson SI, 1965. Predation, body size, and composition of plankton. Science 150:28-35.

Chandler DC, 1940. Limnological studies of Western Lake Erie. 1, Plankton and certain physical-chemical data of the Bass Islands Region, from September, 1938, to November, 1939. Ohio J. Sci. 11:291-336.

Christoffersen KS, Amsinck SL, Landkildehus F, Lauridsen TL, Jeppesen E, 2008. Lake flora and fauna in relation to icemelt, water temperature and chemistry at Zackenberg. Adv Ecol Res 40:371-389.

De Senerpont Domis LN, Elser JJ, Gsell AS, Huszar VLM, Ibelings BW, Jeppesen E, Kosten S, Mooij WM, Roland F, Sommer U, Van Donk E, Winder M, Lürling M, 2012. Plankton dynamics under different climatic conditions in space and time. Freshwater Biol. 58:463-482.

Dokulil MT, Herzig A, 2009. An analysis of long-term winter data on phytoplankton and zooplankton in Neusiedler See, a shallow temperate lake, Austria. Aquat. Ecol. 43:715-725.

Edmondson W, 1965. Reproductive rate of planktonic rotifers as related to food and temperature in nature. Ecol. Monogr. 35:61-111.

Forsström L, Sorvari S, Rautio M, Sonninen E, Korhola A, 2007. Changes in physical and chemical limnology and plankton during the spring melt period in a subarctic lake. Hydrobiology 92:301-325.

Galloway AW, Taipale SJ, Hiltunen M, Peltomaa E, Strandberg U, Brett MT, Kankaala P, 2014. Diet $\square$ specific biomarkers show that high $\square$ quality phytoplankton fuels herbivorous zooplankton in large boreal lakes. Freshwater Biol. 59:1902-1915.

Gillooly JF, 2000. Effect of body size and temperature on generation time in zooplankton. J. Plankton Res. 22:241-251.

Grey J, Jones RI, Sleep D, 2001. Seasonal changes in the importance of the source of organic matter to the diet of zooplankton in Loch Ness, as indicated by stable isotope analysis. Limnol. Oceanogr. 46:505-513.

H. J. Dumont, Velde IVD, Dumont S, 1975. The dry weight estimate of biomass in a selection of Cladocera, Copepoda and Rotifera from the plankton, periphyton and benthos of continental waters. Oecologia 19:75-97.

Halvorsen G, 2004. Some physical and chemical characteristics of Lake Atnsjøen. Hydrobiologia 521:129-140.

Halvorsen G, Dervo BK, Papinska K, 2004. Zooplankton in Lake Atnsjøen 1985-1997. Hydrobiologia 521:149-175.

Hampton SE, Galloway AW, Powers SM, Ozersky T, Woo KH, Batt RD, Labou SG, O'reilly CM, Sharma S, Lottig NR, 2017. Ecology under lake ice. Ecol. Lett. 20:98-111.

Hampton SE, Moore MV, Ozersky T, Stanley EH, Polashenski 
CM, Galloway AWE, 2015. Heating up a cold subject: prospects for under-ice plankton research in lakes. J. Plankton Res. 37:277-284.

Hart RC, Bychek EA, 2011. Body size in freshwater planktonic crustaceans: an overview of extrinsic determinants and modifying influences of biotic interactions. Hydrobiologia 668:61-108.

Hessen DO, Andersen T, Brettum P, Faafeng BA, 2003a. Phytoplankton contribution to sestonic mass and elemental ratios in lakes: Implications for zooplankton nutrition. Limnol. Oceanogr. 48:1289-1296.

Hessen DO, Faafeng BA, Brettum P, 2003b. Autotroph : herbivore biomass ratios; carbon deficits judged from plankton data. Hydrobiologia 491:167-175.

Hindar K, Jonsson B, 1982. Habitat and food segregation of dwarf and normal Arctic charr (Salvelinus alpinus) from Vangsvatnet Lake, western Norway. Can. J. Fish. Aquat. Sci. 39:1030-1045.

Holm S, 1979. A simple sequentially rejective multiple test procedure. Scand. J. Stat. 6:65-70.

IBM, 2017. IBM SPSS Statistics for Windows. 25. Armonk.

Jeppesen E, Jensen JP, Jensen C, Faafeng B, Hessen DO, Søndergaard M, Lauridsen T, Brettum P, Christoffersen K, 2003. The impact of nutrient state and lake depth on top-down control in the pelagic zone of lakes: A study of 466 lakes from the temperate zone to the arctic. Ecosystems 6:313-325.

Kibby HV, 1971. Energetics and population dynamics of Diaptomus gracilis. Ecol. Monogr. 41:311-327.

Kloster AE, 1978. Physical and chemical properties of the waters of Øvre Heimdalen. Ecography 1:117-123.

Lampert W, Trubetskova I, 1996. Juvenile growth rate as a measure of fitness in Daphnia. Funct. Ecol. 10:631-635.

Langeland A, Reinertsen H, 1982. Interactions between phytoplankton and zooplankton in a Fertilized Lake. Holarctic Ecol 5:253-272.

Larsson P, 1978. The life cycle dynamics and production of zooplankton in Øvre Heimdalsvatn. Holoarctic Ecology $1: 162-218$.

Larsson P, Brittain JE, Lien L, Lillehammer A, Tangen K, 1978. The Lake Øvre Heimdalsvatn: A subalpine freshwater ecosystem. Holarctic Ecol. 1:304-320.

Liu Q, 1997. Variation partitioning by partial redundancy analysis (RDA). Environmetrics 8:75-85.

Loose CJ, Dawidowicz P, 1994. Trade-offs in diel vertical migration by zooplankton: The costs of predator avoidance. Ecology 75:2255-2263.

Mohr M. 2008. New routines for gridding of temperature and precipitation observations for "seNorge.no". Norwegian Meteorological Institute. Technical Report. 8: 40 pp.

Mohr M. 2009. Comparison of versions 1.1 and 1.0 of gridded temperature and precipitation data for Norway. Norwegian Meteorological Institute. Technical Report. 19: 44 pp.

Nilssen JP, 1977. Cryptic predation and the demographic strategy of two limnetic cyclopoid copepods. Mem. Ist. Ital. Idrobiol. 34:187-196.

Noges T, Kisand V, Noges P, Pollumae A, Tuvikene L, Zingel P, 1998. Plankton seasonal dynamics and its controlling factors in shallow polymictic eutrophic lake Vortsjarv, Estonia. Int Rev Hydr 83:279-296.

Nordli PO, Grimenes AA, 2004. The climate of Atndalen. Hydrobiologia 521:7-20.
Obertegger U, Obrador B, Flaim G, 2017. Dissolved oxygen dynamics under ice: Three winters of high-frequency data from Lake Tovel, Italy. Water Resour. Res. 53:7234-7246.

Økland RH, 1990. Vegetation ecology: theory, methods and applications with reference to fennoscandia. Sommerfeltia 1:1-172.

Post E, Forchhammer MC, Bret-Harte MS, Callaghan TV, Christensen TR, Elberling B, Fox AD, Gilg O, Hik DS, Hoye TT, Ims RA, Jeppesen E, Klein DR, Madsen J, Mcguire AD, Rysgaard S, Schindler DE, Stirling I, Tamstorf MP, Tyler NJC, Van Der Wal R, Welker J, Wookey PA, Schmidt NM, Aastrup P, 2009. Ecological dynamics across the Arctic associated with recent climate change. Science 325:1355-1358.

Rautio M, Mariash H, Forsström L, 2011. Seasonal shifts between autochthonous and allochthonous carbon contributions to zooplankton diets in a subarctic lake. Limnol. Oceanogr. 56:1513-1524.

Rocha O, Duncan A, 1985. The relationship between cell carbon and cell volume in freshwater algal species used in zooplankton studies. J. Plankton. Res. 7:279-294.

Saksgård R, Hesthagen T, 2004. A 14-year study of habitat use and diet of brown trout (Salmo trutta) and Arctic charr (Salvelinus alpinus) in Lake Atnsjøen, a subalpine Norwegian lake. Hydrobiologia 521:187-199.

Salonen K, Lepparanta M, Viljanen M, Gulati RD, 2009. Perspectives in winter limnology: closing the annual cycle of freezing lakes. Aquat. Ecol. 43:609-616.

Santer B, 1993. Do cyclopoid copepods control Daphnia populations in early spring, thereby protecting their juvenile instar stages from food limitation? Intern. Ver. Theor. Verh. Angew. Limnol. 25:634-637.

Sommer U, Adrian R, De Senerpont Domis LN, Elser JJ, Gaedke U, Ibelings BW, Jeppesen E, Lürling M, Molinero JC, Mooij WM, Van Donk E, Winder M, 2012. Beyond the Plankton Ecology Group (PEG) model: Mechanisms driving plankton succession. Annu Rev Ecol Syst 43:429-448.

Sommer U, Gliwicz ZM, Lampert W, Duncan A, 1986. The PEG-model of seasonal succession of planktonic events in fresh waters. Arch. Hydrobiol. 106:433-471.

Standards Norway, 1987. Water quality - Guidelines for the determination of total organic carbon (TOC) - Norm no. NSISO8245.

Steinhart GB, Wurtsbaugh WA, 2003. Winter ecology of kokanee: Implications for salmon management. T. Am. Fish. So.c 132:1076-1088.

Stemberger RS, Gilbert JJ, 1985. Body size, food concentration, and population growth in planktonic rotifers. Ecology 66:1151-1159.

Ter Braak CJF, Šmilauer P, 2012. CANOCO Reference Manual and User's Guide: Software for Ordination (ver. 5.0). Microcomputer Power, Ithaca.

Urabe J, 1991. Effect of food concentration on growth, reproduction and survivorship of Bosmina longirostris (Cladocera) - an experimental study. Freshwater Biol. 25:1-8.

Virro T, Haberman J, Haldna M, Blank K, 2009. Diversity and structure of the winter rotifer assemblage in a shallow eutrophic northern temperate Lake Vrtsjarv. Aquat. Ecol. 43:755-764.

Walz N, 1995. Rotifer populations in plankton communities: Energetics and life history strategies. Experientia 51:437-453. 
Watz J, Bergman E, Calles O, Enefalk A, Gustafsson S, Hagelin A, Nilsson PA, Norrgard JR, Nyqvist D, Osterling EM, Piccolo JJ, Schneider LD, Greenberg L, Jonsson B, 2015. Ice cover alters the behavior and stress level of brown trout Salmo trutta. Behav. Ecol. 26:820-827.

Weyhenmeyer GA, Peter H, Willen E, 2013. Shifts in phytoplankton species richness and biomass along a latitudinal gradient consequences for relationships between biodiversity and ecosystem functioning. Freshwater Biol. 58:612-623.
Wickham SA, Gilbert JJ, Berninger UG, 1993. Effects of rotifers and ciliates on the growth and survival of Daphnia. J. Plankton Res. 15:317-334.

Winder M, Cloern JE, 2010. The annual cycles of phytoplankton biomass. Philos. T. R. Soc. B 365:3215-3226.

Winder M, Sommer U, 2012. Phytoplankton response to a changing climate. Hydrobiologia 698:5-16.

Zaret TM, 1980. Predation and freshwater communities. Yale University Press, New Haven/London: 187 pp. 